\section{Soviet data made public}

\section{London}

RADIOACTIVE contamination from Chernobyl is still "an acute technical and social problem" likely to persist for a considerable time, according to Dr Yurii Izrael, chairman of the State Committee for Hydrometeorology, writing in Pravda last week. In a full-page article, he presented the first figures and maps for the whole area of the Soviet Union affected, comprehensively extending the data for Byelorussia given at a public meeting in Minsk last month (see Nature 337, 683; 28 February 1989).

The release of these data is an important development, a departure from the policy described by Kiev radio earlier this month as the "tranquillizing" of the population. Contrary to the impression conveyed at Minsk that the collection of data had only just been completed, Izrael also says that the collection of data began on 26 April 1986, the day after the covering a 60 - by $40-\mathrm{km}$ region showing contours of gamma-radiation was available on 10 May that year, in time to guide the evacuation of people from contaminated zones.

In the first few days after the accident, Izrael says, the first 2 milliroentgen per hour contour enclosed about 200,000 $\mathrm{km}^{2}$ of Soviet territory, with islands of contamination as far away as the Kola Peninsula in the far north, Ivano-Frankovsk in the south-west and the Caucausus in the south-east.

"Massive" testing of soil samples began in June 1986, when exceptionally high proportions of the long-lived isotopes caesium-134 and caesium-137 were found. But Izrael says that the lifetime exposure limit of 35 rem of external radiation was applied to the caesiumlimits. accident, and that a generalized map

contaminated areas only in November 1988 , leading to the evacuation of a further 20 villages in Byelorussia.

Pollution of rivers and reservoirs remained "within the limits of the agreed norms" in the months after the accident, according to Izrael, who says that total beta-activity amounted to between 1 and $6 \times 10^{-9}$ curie per litre during the first two months. (The safety limit was $10^{-8}$ curie per litre.) During the spring floods of 1987, Izrael says, even the rivers with radiation 'hotspots' in their catchment areas were well below the limit.

Further aerial and ground surveys carried out in 1988 are said to have revealed substantial changes of the contours. At present, Izrael says, for caesium-137 the 15 curie per $\mathrm{km}^{2}$ contour encloses some $10,000 \mathrm{~km}^{2}$, of which some $3,500 \mathrm{~km}^{2}$ have been evacuated, while the remainder has a population of 230,000 people. In the town of Slatytych, built for Chernobyl workers after the accident, radiation levels $(0.013$ to 0.03 milliroentgen per hour) are close to the natural background, although there are some hotspots in the surrounding forests which nevertheless do not exceed the safety

Although Izrael's sympathy for the new anti-nuclear groups in the Soviet Union is clearly muted, he concedes that the decision to close the two Armenian reactors (at Yerevan, one last month and one this) was "quite understandable". But he concludes that, with the threat of the greenhouse effect, nuclear generation is the "most promising" form of energy. The lessons of Chernobyl, he says, imply that the operation of existing nuclear reactors is "many times", and of future stations, "many orders of magnitude", safer than in the past. Vera Rich

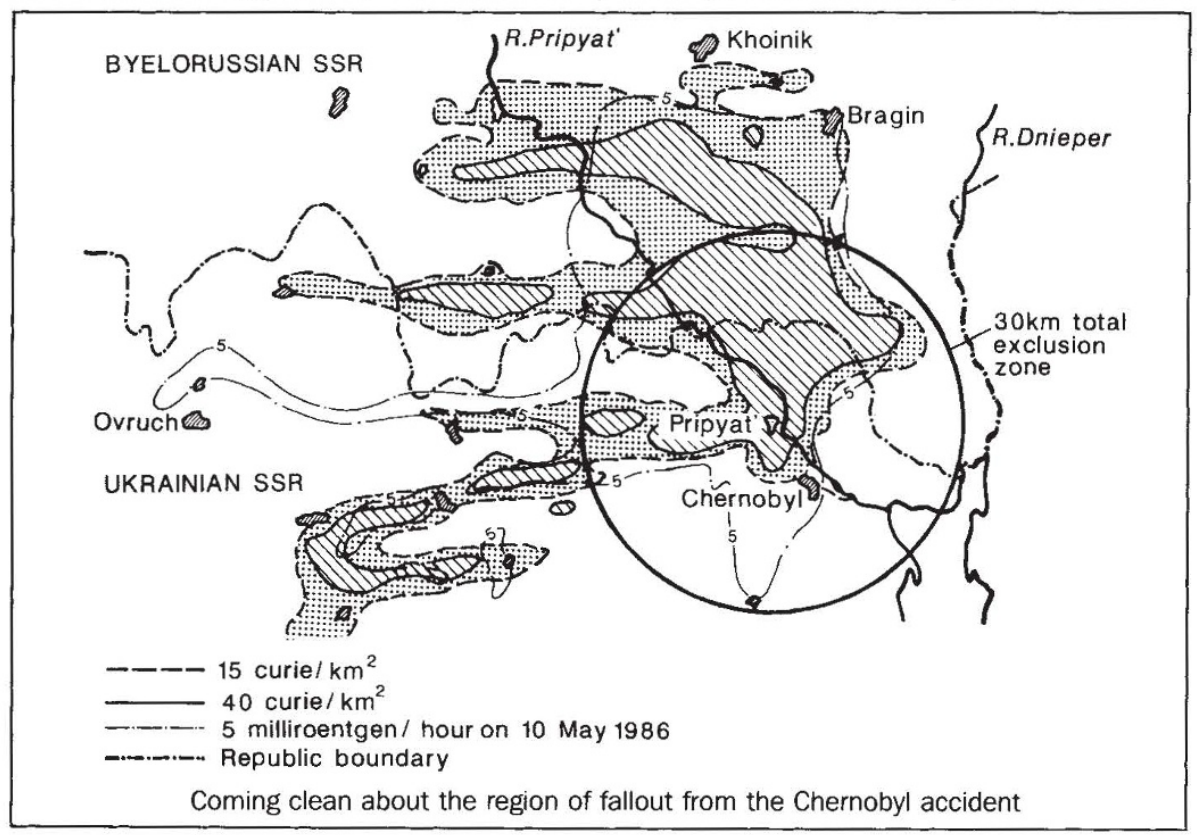

\section{resana French drug under attack} Paris

THE controversial abortion pill RU-486, which was approved by the French Health Ministry for use in abortion clinics last year amid angry opposition, is again under attack (see Nature 336, 4; 1988). Dr John Willke, of the US National Right to Life Coalition, is in Europe for the annual meeting of the International Federation for the Right to Life in Brussels. Before the meeting he met the medical research director of RousselUCLAF, the company that makes the drug, and suggested that the company's products could be boycotted in the United States if the drug is not withdrawn.

France is the only country to have legalized the use of RU-486 for abortion, and the drug is administered only under strict medical supervision and only in association with prostaglandins. In October last year, Roussel-UCLAF suspended sales of the drug after some of its senior employees and their families received anonymous death threats. It was only after government intervention that the drug was again put on the market.

Roussel-UCLAF, a subsidiary of the pharmaceuticals giant Hoechst, declined to comment on the meeting with Willke. A spokesman said that RU-486 is only a new alternative to surgery and its withdrawal would have no effect on the number of abortions carried out. In Washington, the National Right to Life Coalition also declined to comment on possible boycott action while Willke is still in Europe.

Right to Life is one of the most vocal and powerful minority lobbies in the United States, capable of assembling thousands of people at rallies to protest against abortion. Any decision to boycott Hoechst products would therefore be taken seriously by the company, even though it has no plans to introduce RU486 in the United States.

Although it is illegal for federal laboratories to carry out research on abortifacients, the potential contraceptive properties of RU-486 are being studied. At low doses, the drug is thought to impair the implantation of a fertilized ovum in the uterus lining. Since implantation is a criterion for pregnancy, such a function would technically be 'contraceptive' and not 'abortifacient'.

There is no national legislation on abortion in the United States; only a Supreme Court ruling makes it illegal for states to outlaw abortion. But a test case currently before the Supreme Court has challenged this ruling. The judgement, which could come in the next month, will stir emotions in the anti-abortion lobby, whatever the outcome.

Peter Coles 